\title{
Mangrove Cultivation For Dealing With Coastal Abrasion Case Study Of Karangsong
}

\author{
Feti Fatimatuzzahroh ${ }^{1 . *}$, Sudharto P. Hadi ${ }^{2}$. Hartuti Purnaweni ${ }^{2}$ \\ ${ }^{1}$ Doctorate Program of Environmental Studies, Diponegoro University, Semarang, Indonesia \\ ${ }^{2}$ Study Program of Environmental Studies, Diponegoro University, Semarang, Indonesia
}

\begin{abstract}
Coastal abrasion is consequence from destructive waves and sea current. One of cause is human intervention. The effort to solve of abrasion is by mangrove cultivation. Mangroves are halophyte plant that can restrain the sea wave. Mangrove cultivation required participation community that give awareness the importance of mangrove in coastal sustainability. Mangroves in coastal Karangsong, Indramayu west java, in 2007 was through abrasion approximately 127.30 ha. Mangrove cultivation in Karangsong has been replanting since 1998 to 2003, but there was no maintenance and management. In 2007 until 2015 Karangsong replanting mangroves and has been succeed. Karangsong became the center of mangrove study for west java area in 2015. This achievement is result of cooperation between community, NGO, and local government. In addition, this effort made not only overcome the abrasion problem but also give community awareness about the importance of mangrove cultivation in preventing coastal abrasion throughout community development. This paper reviews abrasion in Karangsong and the impact for local community and empowerment in mangrove cultivation. To achieve the success mangrove cultivation required community development approach from planning process, planting, maintenance and management.
\end{abstract}

\section{Introduction}

Coastal abrasion is a common problem facing coastal Indonesia. At least recorded from the 99,093 km long coastline of Indonesia, The ministry of Marine Affairs and Fishery said that rate of abrasion in Indonesia is 1.950 ha per years with average coastline $420 \mathrm{~km} /$ years. Abrasion is caused by a wave of seawater that hit the shoreline with no wave retention so as to erode the erosion of the beach. The destruction of coastal areas has had a social and economic impact on the surrounding communities. Most coastal damage is an abrasion caused by the loss of mangrove forests as a natural protector in coastal areas. Mangrove cultivation is required to restore the affected coastal areas. Community development approach is needed in successful mangrove cultivation to overcome coastal abrasion.

Karangsong is a coastal area located in Indramayu, West Java, has been started mangrove cultivation activities to overcome coastal abrasion. Since 2007 the government with the local community has been replanting mangrove but because there is no good management, mangrove cultivation did not succeed and produce mangrove forest along the coastline of Karangsong. In 2015 Karangsong set as the center of mangrove studies for the western part of Java. The factor that moves society and government Karangsong to do mangrove cultivation is the number of ponds that have been affected by abrasion so that people Karangsong both ponds and fish yield from ponds also decreased. This journal reviews abrasion in Karangsong and its impact on local residents. The questions addressed are (1) How cultivation of mangroves in Karangsong? (2) What is the impact of mangrove cultivation on abrasion in coastal Karangsong? (3) And what are the barriers to mangrove cultivation in Karangsong related to community empowerment?

\section{Literature review}

Community development in coastal area is to build and maintain local biological diversity and to solve their problem with their local potential. Community refers to village-level or single goods-level activities [1]. Indonesia has a rich biological diversity that Foucat and Jones argued rationale for developing community-based management is to build upon and maintain local, ethnic and biological diversity[2,3]. Community involvement in management and conservation activities encourages to a local conservation commitment and can improve a

"Corresponding author: feti.faza@gmail.com 
community's ability to sustainably manage natural resources through generating appropriate norms and rules and enhancing trust and reciprocity.

Community development has a variety of strategies that are less effective than others [4]. Furthermore, Pomeroy (1994) mentions that community management approach represents an essential practice to reach sustainability. And community management can have the effect of intensify long state control (where some may desire while others resist) and denying people the space to change, to privatize property, and to invent alternate resource management regimes in their own interest [5].

\section{Research methodology}

This research used descriptive analysis method that depict mangrove cultivation and its impact in overcoming abrasion. The study included (a) mangrove cultivation (b) impact of mangrove cultivation on abrasion (c) barriers to mangrove cultivation. Data collection used primary data which is information from impact of mangrove planting to abrasion and secondary data which is abrasion data and mangrove cultivation. The case study was conducted in Karangsong, Indramayu, West Java.

\section{The result and discussion}

Mangrove cultivation in Karangsong has been done since 1998. At that time there was an offer of coastal reforestation cooperation with Wetland International and was an effort of environmental conservation group that focuses on pond program with environmentally based. Care and maintenance of mangrove is done in pond owned by pond farmers. Furthermore, the mangrove cultivation effort was replanting in 2004 with the government program from the Ministry of Forestry, but failed due to the internal problems of the group. In addition, there was no management and maintenance in mangrove cultivation became the main factor of such failure so that mangrove cultivation were abandoned. In 2008 mangrove cultivation was carried out by Pantai Lestari group with focus of coastal greening and nurturing mangrove seedlings, procurement of buffer zone with planting, and maintenance and mangrove embankment. The mangrove cultivation is in cooperation with Ministry of Public Works, Regency Government, Ministry of Marine Affairs and Fisheries, Ministry of Environment, CSR PT PertaminaBalongan RU VI, PT Traktor Nusantara Jakarta, KEHATI Foundation and $\mathrm{MfF}$ Indonesia. Here is the data of mangrove planting in Karangsong.
Table 1 Mangrove Planting in Karangsong, Indramayu

\begin{tabular}{|c|c|c|}
\hline Year & Data of Mangroves Planting & $\begin{array}{l}\text { Amount } \\
\text { (Trees) }\end{array}$ \\
\hline 2008 & $\begin{array}{l}\text { BBWS Cimanuk-Cisanggarung } \\
\text { (Ministry of Public Works and } \\
\text { Public Housing) }\end{array}$ & 25.000 \\
\hline 2009 & $\begin{array}{l}\text { TP - APBN DISKANLA Regency } \\
\text { of Indramayu }\end{array}$ & 50.000 \\
\hline 2010 & $\begin{array}{l}\text { RU VI - PT. PertaminaBalongan - } \\
\text { CSR }\end{array}$ & 5.000 \\
\hline \multirow[t]{2}{*}{2011} & KEHATI Foundation, Jakarta & 11.000 \\
\hline & $\begin{array}{l}\text { BPHM Region } 1 \text { Bali- Ministry of } \\
\text { Environment and Forestry }\end{array}$ & 50.000 \\
\hline \multirow[t]{3}{*}{2012} & $\begin{array}{l}\text { RU VI - PT. Pertamina Balongan - } \\
\text { CSR }\end{array}$ & 10.000 \\
\hline & $\begin{array}{l}\text { Dekon Ministry of Marine Affairs } \\
\text { and Fisheries }\end{array}$ & 25.000 \\
\hline & $\begin{array}{l}\text { PT. Traktor Nusantara Jakarta - } \\
\text { CSR }\end{array}$ & 6.000 \\
\hline 2013 & $\begin{array}{l}\text { Dekon Ministry of Marine Affairs } \\
\text { and Fisheries }\end{array}$ & 20.300 \\
\hline \multirow[t]{2}{*}{2014} & $\begin{array}{l}\text { Dekon Ministry of Marine Affairs } \\
\text { and Fisheries }\end{array}$ & 21.000 \\
\hline & MFF Indonesia (PBB - UNDP) & 50.000 \\
\hline \multirow[t]{2}{*}{2015} & $\begin{array}{l}\text { Dekon Ministry of Marine Affairs } \\
\text { and Fisheries }\end{array}$ & 21.000 \\
\hline & $\begin{array}{l}\text { Ministry of Marine Affairs and } \\
\text { Fisheries }\end{array}$ & 306.500 \\
\hline
\end{tabular}

Source: Pantai Lestari Group (2015)

The impact of mangrove cultivation is the return of shifting beach into green area by dividing area for buffer zone and pond area in Karangsong. Currently, the mangrove area in Karangsong reaches 20 hectares of mangrove land and set as mangroves eco-tourism, 5 ha for arboretum, and 49 ha for mangroves reforestation with land belonging to a group of fishermen purchased and stipulated. To avoid mutual claims of the region in mangroves forest, in 2009 set Perdes (Village Regulation) that ruled that mangrove forest is a conservation and protection areas.

Barriers to mangrove cultivation related with community empowerment that community participation is still oriented to direct economic benefits. People who invited to participate in mangroves cultivation used as planting labor for later given wages. This is because people still do not want to be involved if there is no direct economic benefits associated with the necessities of life. 


\section{The problem}

The efforts of community involvement are still planting as laborers. That's because people are still reluctant to participate in planting personal consciousness without providing direct economic benefits. So that the awareness of the importance of mangrove is still limited from the economic side. Maintenance is also still done by Lestari Beach Group which is a local group in Karangsong which initiated Karangsong coastal reforestation program.

\section{Conclusion and recommendation}

Mangrove cultivation required community development approach from planning process, planting, maintenance and management. In addition, long-term assistance is needed in community engagement efforts for mangrove cultivation in an effort to cope with abrasion.

\section{References}

1. R. S. Pomeroy and M. B. Carlos, "Communitybased coastal resource management in the Philippines: a review and evaluation of programs and projects , 1984-1994," vol. 21, no. 5, pp. 445464, 1997.

2. V. S. A. Foucat, "Community-based ecotourism management moving towards sustainability, in Ventanilla, Oaxaca, Mexico," cean Coast. Manag., vol. 45, pp. 511-529, 2002.

3. Jones, "COMMUNITY-BASED ECOTOURISM The Significance of Social Capital," vol. 32, no. 2, pp. 303-324, 2005

4. T. K. Bradshaw, "Theories of Poverty and AntiPoverty Programs in Community Development Theories of Poverty and Anti-Poverty Programs in Community Development," J. Community Dev. Soc., vol. 38, no. November 2014, pp. 37-41, 2007.

5. [5] G. P. Manatee and J. M. Belsky, "Misrepresenting Communities: The Politics of Community-Based Rural Ecotourism i n," vol. 64, no. 4, pp. 641-666, 1999. 